УДК 53.097

DOI: https://doi.org/10.26642/ten-2020-1(85)-53-59

Ю.І. Коваленко, ст. викладач

М.О. Бондаренко, д.т.н., доц.

Черкаський державний технологічний університет

В.С. Антонюк, д.т.н., проф.

Наиіональний технічний університет Украӥни

«Київський політехнічний інститут імені Ігоря Сікорського»

\title{
Дослідження вольт-амперних характеристик дротяної електронної гармати Пірса для електронно-променевої мікрообробки діелектриків
}

Розглянуто основні енергетичні характеристики дротяної електронно-променевої гармати Пірса, щзо використовується для мікрообробки діелектричних матеріалів у вакуумі. Досліджено режими роботи такої гармати залежно від їх енергетичних характеристик. Встановлено, що за фіксованої ширини анодної щілини у 2,0 мм можна реалізувати основні технологічні режими низькоенергетичної ЕПМО діелектриків (у тому числі оптичного скла).

Проведено порівняння результатів електронно-променевої мікрообробки діелектриків 3 результатами їх лазерної поверхневої обробки. Встановлено зменшення залишкових мікронерівностей поверхні для оптичного скла K8 до 26 разів за електронно-променевої мікрообробки (ЕПМО) та до 14 разів за поверхневої лазерної обробки. Показано, щчо обробка електронним потоком стрічкової форми на відміну від поверхневої лазерної обробки дозволяє повністю усунути хвилястість оптичної поверхні.

На прикладі пластин з оптичного скла К8 доведено, що електронно-променева мікрообробка поверхонь діелектричних матеріалів дозволяє підвищити відтворюваність результатів такоі мікрообробки за чистотою та залишковим нанорельєфом на $18 . .25 \%$.

Ключові слова: електронно-променева гармата Пірса; вольт-амперні характеристики; електронно-променева мікрообробка; діелектричні матеріали.

Актуальність дослідження. Сучасний рівень розвитку науки та техніки ставить низку вимог до елементів виробів наукомісткого обладнання, серед яких: висока надійність, мініатюрність, прецизійність та точність їхного виконання [1]. Особлива увага при цьому приділяється виробам із сучасних діелектричних матеріалів (оптичного скла, кераміки, композиційних та метаматеріалів), які зарекомендували себе як надійний, а іноді й безальтернативний замінник традиційних конструкційних матеріалів. Водночас застосування таких діелектриків вимагає високоякісної підготовки їх поверхонь. Як показано в [2], перспективним методом такої поверхневої обробки цих матеріалів $\epsilon$ метод низькоенергетичної електронно-променевої мікрообробки.

Постановка проблеми. Відомо [3], що мініатюризація та розширення функціональних властивостей елементів виробів 3 діелектричних матеріалів, які виготовляються за традиційними технологіями із залученням методів механічного, хіміко-механічного, полум'яного полірування, обмежується наявністю дефектного приповерхневого шару, що значно знижує техніко-експлуатаційні характеристики цих виробів.

Серед перспективних методів обробки діелектричних матеріалів із залученням концентрованих потоків енергії зарекомендував себе метод стрічкової електронно-променевої мікрообробки (ЕПМО) [4] як такий, що дозволяє не лише зменшити залишковий мікрорельєф поверхні до одиниць нанометрів, але й повністю усунути дефектний та тріщинуватий приповерхневі шари в діелектрику шляхом проплавлення поверхні на глибину до 10 мкм. Інструментом такої обробки є електронний потік стрічкової форми, що генерується дротяним вольфрамовим катодом електронно-променевої гармати (ЕПГ) Пірса, конструкція та принцип дії якої детально розглянуті в [5].

Аналіз останніх досліджень і публікацій. Як зазначається авторами роботи [6], метод ЕПМО із залученням ЕПГ Пірса було використано під час поверхневого полірування пластин із силікатного оптичного скла, що дозволило отримати бездефектні поверхні із залишковими нерівностями до 5 нм 3 повним усуненням у них приповерхневого дефектного шару. При цьому режим такої обробки обирався шляхом експериментальних досліджень і не може бути застосований для якісної поверхневої ЕПМО, наприклад, асферичних поверхонь.

Основним показником якісної ЕПМО діелектричних матеріалів є дотримання рівномірності закону розподілу енергії електронної стрічки та стабільності цього розподілу в процесі руху електронної стрічки вздовж поверхні, що підлягає обробці.

За методикою, що описана в [7], шляхом підбору геометричних параметрів ЕПГ Пірса показано можливість отримання рівномірного за розподілом енергії стрічкового електронного потоку. При цьому відхилення ширини електронного потоку відносно розміру його центральної частини (а відповідно, й 
розподіл енергії електронної стрічки) для відстаней 10..40 мм від ЕПГ до поверхні, що підлягала обробці, не перевищувала $2 . .5 \%$. Проте така методика не дозволяє динамічно керувати розподілом потужності в електронній стрічці, має низьку стабільність (температура та час розігріву катода суттєво збільшують його опір, що стає причиною зменшення енергетичних показників електронного потоку), що призводить до необхідності ручного корегування струмом електронного потоку та прискорюючої напруги.

Тому актуальним є дослідження енергетичних вольт-амперних характеристик (ВАХ) дротяної ЕПГ Пірса для отримання стабільного розподілу енергії електронної стрічки в процесі якісної ЕПМО діелектричних матеріалів.

Метою роботи $\epsilon$ визначення оптимальних режимів електронно-променевої мікрообробки діелектричних матеріалів шляхом дослідження вольт-амперних характеристик дротяної електроннопроменевої гармати Пірса.

Порядок проведення експериментальних досліджень. Експериментальні дослідження проводилися на модернізованій вакуумній установці УВН-71, яка містить ЕПГ Пірса (діаметр катода 0,4 мм, довжина катода 90 мм, довжина щілини анода $a=80$ мм, ширина щілини анода $b_{a}=2$ мм), що генерує електронний потік стрічкової форми довжиною 60 мм. Робочі характеристики електроннопроменевої гармати Пірса: максимальний струм розігріву катода $I_{f}=50 \mathrm{~A} \pm 15 \%$; діапазон прискорюючої напруги $U_{n p u c}=1,5 \ldots 12 \mathrm{\kappa B} \pm 2 \ldots 3 \%$; діапазон струмів електронного потоку $I_{\text {nom }}=50 \ldots 500 \mathrm{~mA} \pm 1 \ldots 5 \%$. Тиск у вакуумній камері під час ЕПМО становить $p_{0}=(3 \ldots 5) 10^{-4}$ Па і реєструється вакуумметром ВМБ-8 (діапазон виміру тисків $100 \ldots 10^{-7}$ Па). Відстань від електронної гармати (зовнішньої поверхні анода) до оброблюваної поверхні становила $\mathrm{H}=40$ мм $\pm 0,1$ мм.

Експериментальна схема дослідження, що наведена на рисунку 1, дозволяє коректно виміряти та дослідити ВАХ дротяної ЕПГ Пірса.

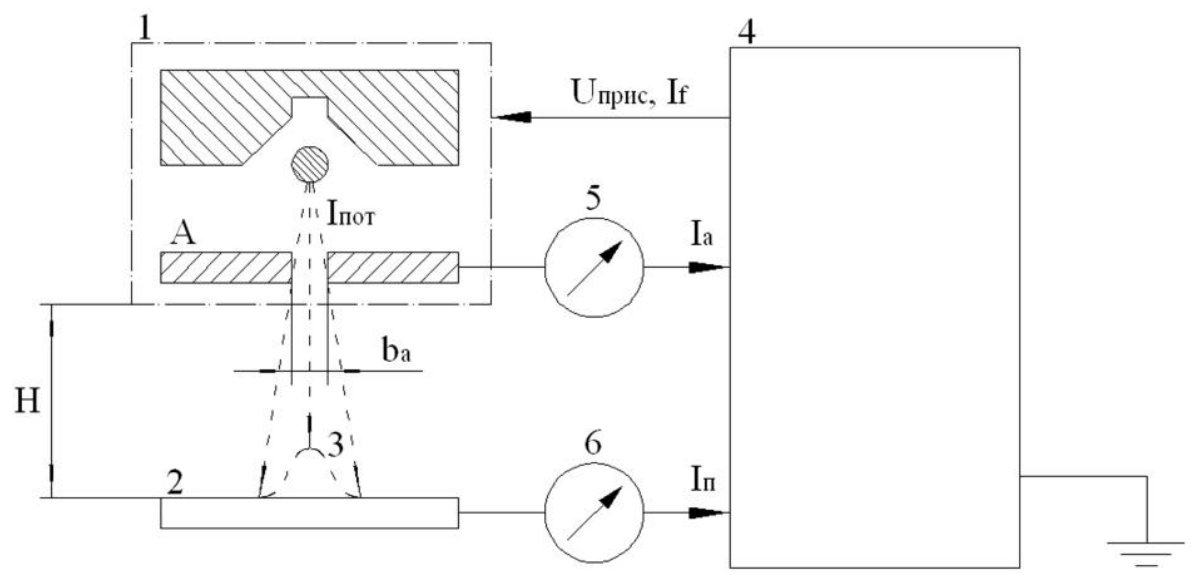

Рис. 1. Експериментальна схема визначення ВАХ на катоді ЕПГ Пірса та на пластині з діелектрика:

1 - ЕПГ Пірса; 2 - пластина з діелектрика; 3 - розподіл електронного потоку стрічкової форми по

поверхні діелектричного матеріалу; 4 - керуючий блок живлення ЕПГ; 5, 6-мультиметри для

вимірювання струму на аноді та на діелектричному матеріалі; $A$ - анод; $H$ - відстань від ЕПГ до

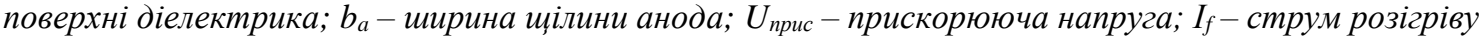

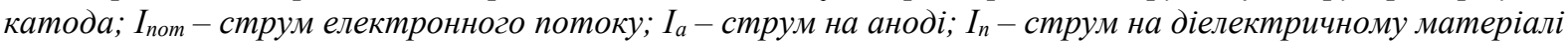

Для візуального спостереження дії електронного потоку використовувався метод зон термічного впливу (3ТВ), описаний у роботі [8], що виникають на пластині зі сталі Х18Н10Т при зміні ії поверхневої структури в результаті нагрівання та відпалювання.

Результати ЕПМО діелектриків, яка проводилася за оптимальних режимів, порівнювалися із результатами лазерної поверхневої обробки, яка здійснювалася на установці «Diar-6» (виробник ТОВ «Араміс», м. Черкаси) скануючим лазерним променем (діаметр променя 200 мкм) за таких режимів: потужність випромінення 15 Вт, швидкість сканування 500 мм/с, фокусна відстань 150 мм.

Дослідження мікрогеометрії поверхонь оптичних пластин після ЕПМО та поверхневої лазерної обробки проводилося на приладі «NT-206V» (виробник ТДВ «Микротестмашины», Білорусь). Водночас було використано кремнієві зонди «Ultrasharp CSC12» (виробник «Mikromasch», Німеччина). До складу приладу також входить система мікропозиціонування і вбудований оптичний довгофокусуючий мікроскоп Logitech (виробник «Logitech Inc», США), які дозволяють проводити вибір необхідної ділянки на поверхні зразка. 
Для підвищення достовірності результатів дослідження вимірювання мікрогеометрії проводилося не менше ніж на 5 зразках, окремо узятих для кожного виду обробки.

Обговорення результатів технологічних експериментів. У результаті проведених технологічних експериментів 3 визначення розподілу струму електронного потоку на аноді та діелектричному матеріалі, який є об’єктом обробки (оптичне скло К8), були отримані залежності струму електронного потоку $I_{n o m}$

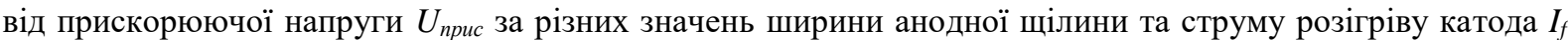
(рис. 2-4).
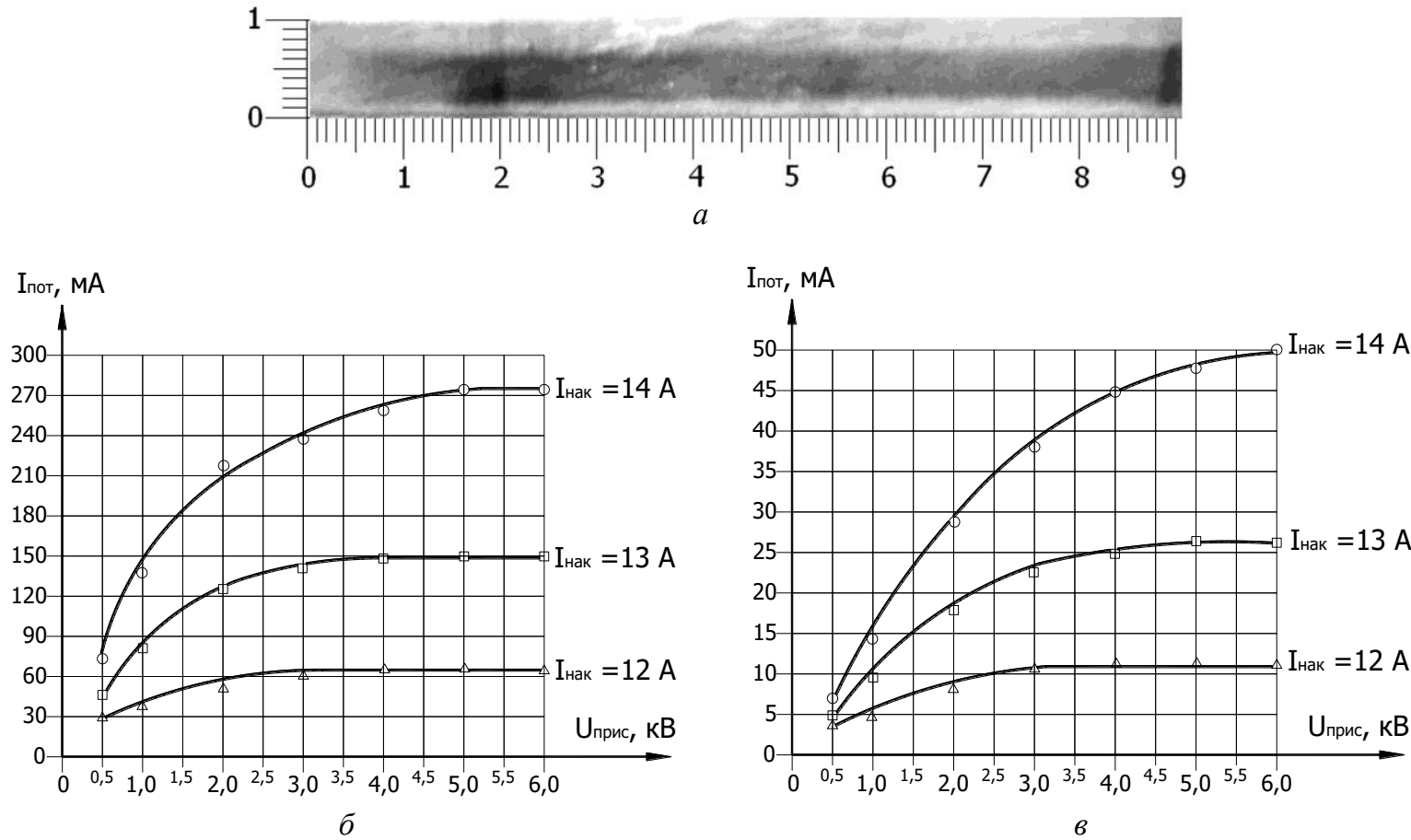

Рис. 2. Характерний вигляд ЗТВ на поверхні пластини зі сталі Х18Н10T (а) від дії електронного потоку

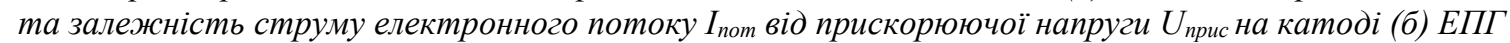

Пірса і на пластині зі скла К8 (в) (ширина щілини анода $b_{a}=2,0$ мм, площа відбитку на оптичній пластині від дії електронної стрічки 4,0 мм × 90 мм)

Для візуального спостереження рівномірності закону розподілу енергії електронної стрічки вздовж поверхні, що підлягає обробці, було використано метод ЗТВ. Ширина, форма й інтенсивність ЗТВ визначалися по центру контрастної смуги, утвореної електронним потоком і розташованої на пластині зі сталі Х18Н10Т під ЕПГ (рис. 2-4, a). Центральна частина ЗТВ максимальної інтенсивності відповідала максимальному тепловому впливу електронного потоку на досліджувану поверхню.

При цьому слід взяти до уваги той факт, що інтенсивність та однорідність розподілу електронного потоку на металевій пластині має більш виражений характер, ніж на пластині з діелектричного матеріалу (оптичне скло К8). Водночас ширина ЗТВ на діелектрику більша за ширину ЗТВ на провіднику в $1,2 \ldots 2,3$ раза за тих же режимів ЕПМО.

Як видно із рисунка 2, за оптимальних геометричних параметрів ЕПГ Пірса, які були отримані в роботі [8], а саме: при ширині анодної щілини $b_{a}=2,0$ мм, залежність струму електронного потоку від прискорюючої напруги як на катоді електронної гармати, так і на пластині зі скла мають високу стабільність у діапазоні прискорюючої напруги $3 \ldots 6$ кВ і струму обробки 30..180 мА (на аноді) та 5...30 мА (на діелектрику) при струмі розжарювання катода до 13 А, що відповідає основним технологічним режимам низькоенергетичної ЕПМО діелектриків (у тому числі оптичного скла), які характерні для II стадії термічного впливу (СТВ).

Це відповідає структурному модифікуванню поверхневого шару діелектриків, при якому відбувається повне переплавлення тріщинуватого та дефектного шарів, у результаті чого утворюється нова структура. На такому модифікуванні грунтуються основні технологічні режими електроннопроменевої мікрообробки виробів із оптичного скла.

Для порівняння на рисунках 3-4 наведено вольт-амперні характеристики для ширини щілини анода $b_{a}=1,5$ мм (рис. 3) та $b_{a}=3,0$ мм (рис. 4). 

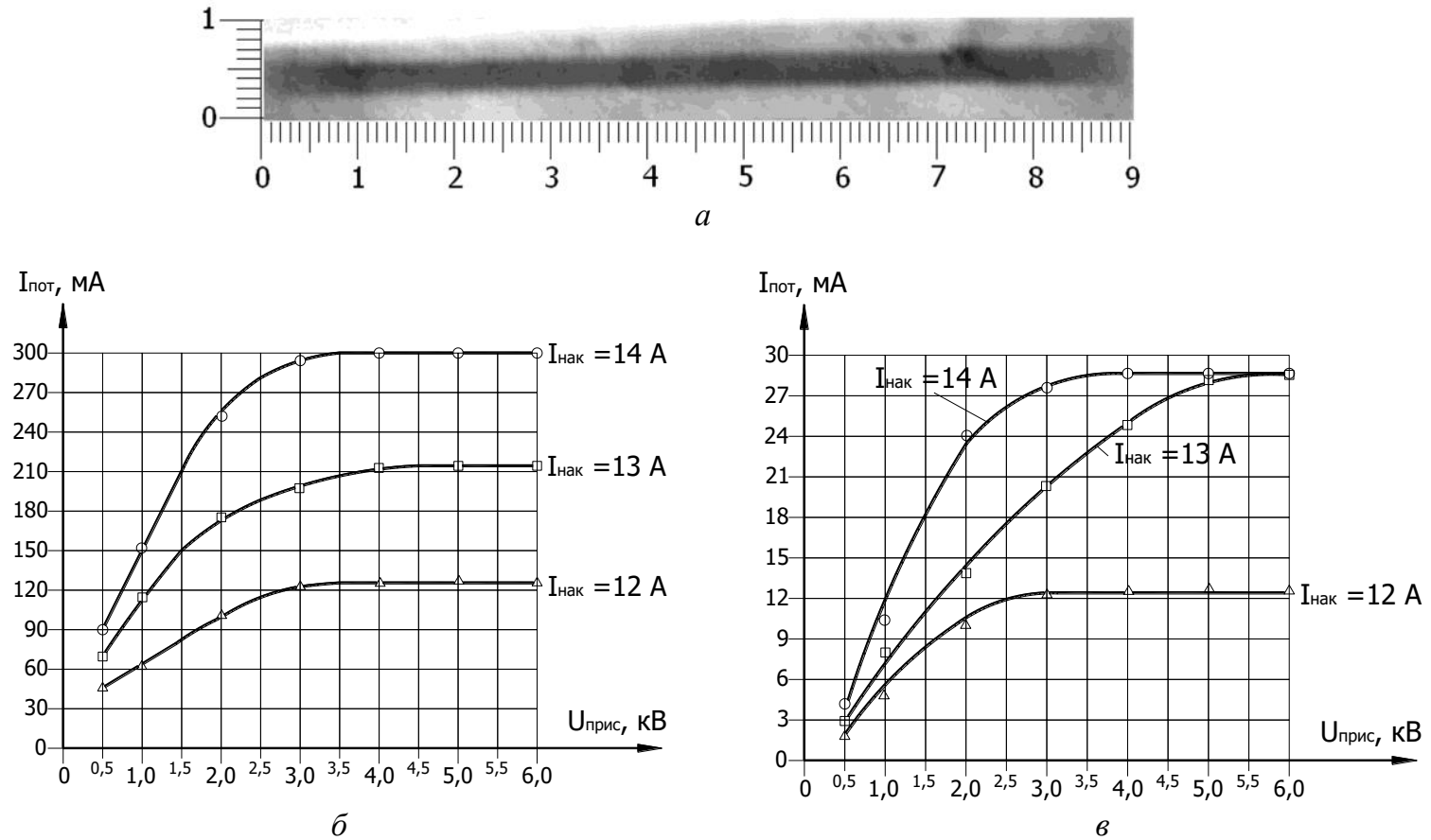

Рис. 3. Характерний вигляд ЗТВ на поверхні пластини зі сталі Х18Н10Т (а) від дї електронного потоку

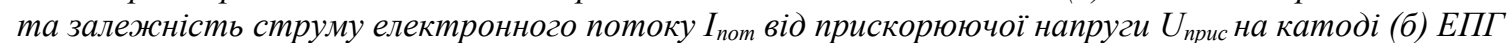

Пірса і на пластині зі скла К8 (в) (ширина щуілини анода $b_{a}=1,5$ мм, площза відбитку на оптичній пластині від дії електронної стрічки 2,7 мм × 90 мм)
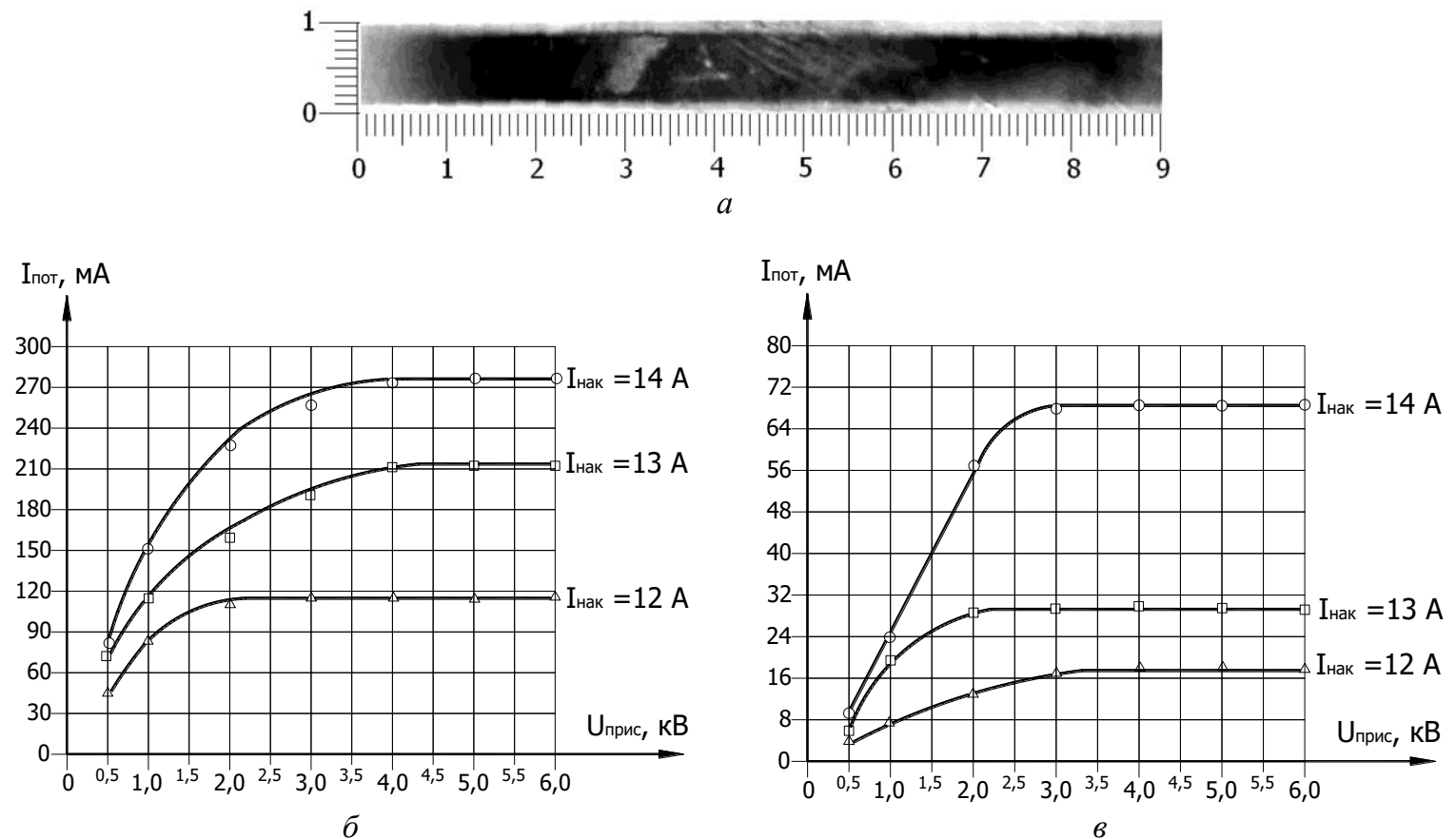

Рис. 4. Характерний вигляд ЗТВ на поверхні пластини зі сталі Х18Н10T (а) від дї електронного потоку

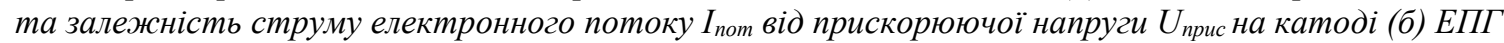
Пірса і на пластині зі скла К8 (в). Ширина щзілни аноду $b_{a}=3,0$ мм, площза відбитку на оптичній пластині від дії електронної стрічки 6,0 мм × 90 мм

На рисунку 3 показано ВАХ на катоді електронної гармати та на пластині зі скла К8 при значенні анодної щілини $b_{a}=1,5$ мм. Результати дослідження цих ВАХ вказують на високу стабільність у діапазоні прискорюючої напруги $3 \ldots 6 \mathrm{\kappa B}$ та струму обробки 30..300 мА (на аноді), тоді як на діелектрику стабільне значення прискорюючої напруги спостерігається лише у діапазоні значень струму 
обробки 5..15 мА, що відповідає лише режимам ЕПМО для I стадії термічного впливу (СТВ), яка характеризується тепловою обробкою поверхонь, що проводиться без утворення в ній рідкої фази.

Водночас при значенні $b_{a}=3,0$ мм (рис. 4) висока стабільність, як і у випадку $b_{a}=2,0$ мм (рис. 2), спостерігається в діапазоні прискорюючої напруги $3 \ldots 6$ кВ та струмі розжарювання катода $12 \ldots 14$ А. При цьому струм електронного потоку на аноді знаходиться у діапазоні значень 30...300 мА, тоді як на діелектрику значення струму обробки збільшуються до 16..70 мА, що відповідає лише режимам ЕПМО для III СТВ, за яких відбувається інтенсивне випаровування і кипіння речовини поверхневого шару оптичного скла, а його практичне використання малоперспективне та вкрай обмежене.

Енергетичні режими обробки, які були отримано в результаті дослідження ВАХ дротяної ЕПГ Пірса, було використано для поверхневого оплавлення пластин 3 оптичного скла К8. За результатами проведеної електронно-променевої мікрообробки діелектриків за оптимальних режимів було проведено ïх порівняння 3 результатами лазерної поверхневої обробки, що виявило зменшення залишкових мікронерівностей поверхні для оптичного скла К8 з 40..110 нм до 1,5 ..6,5 нм за електронно-променевої мікрообробки та до 3,3...7,8 нм за поверхневої лазерної обробки (рис. 5).

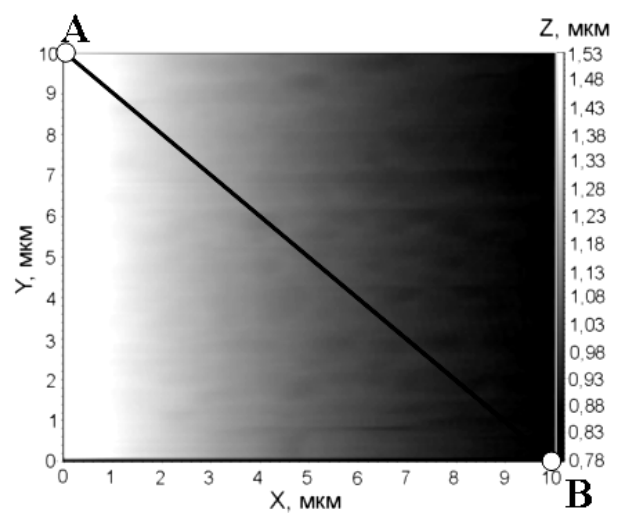

$a$

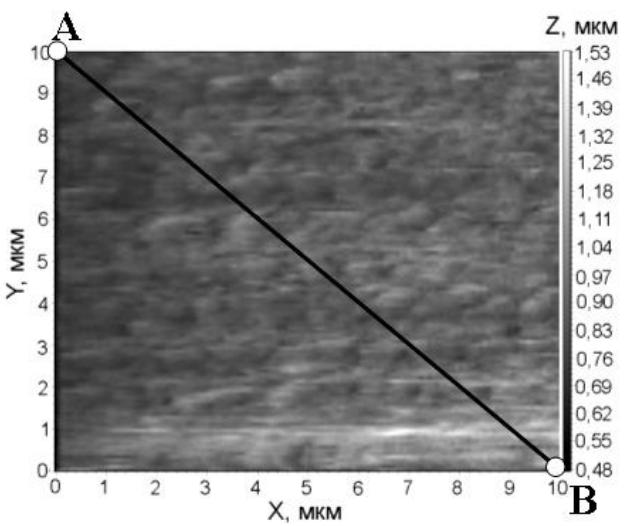

6

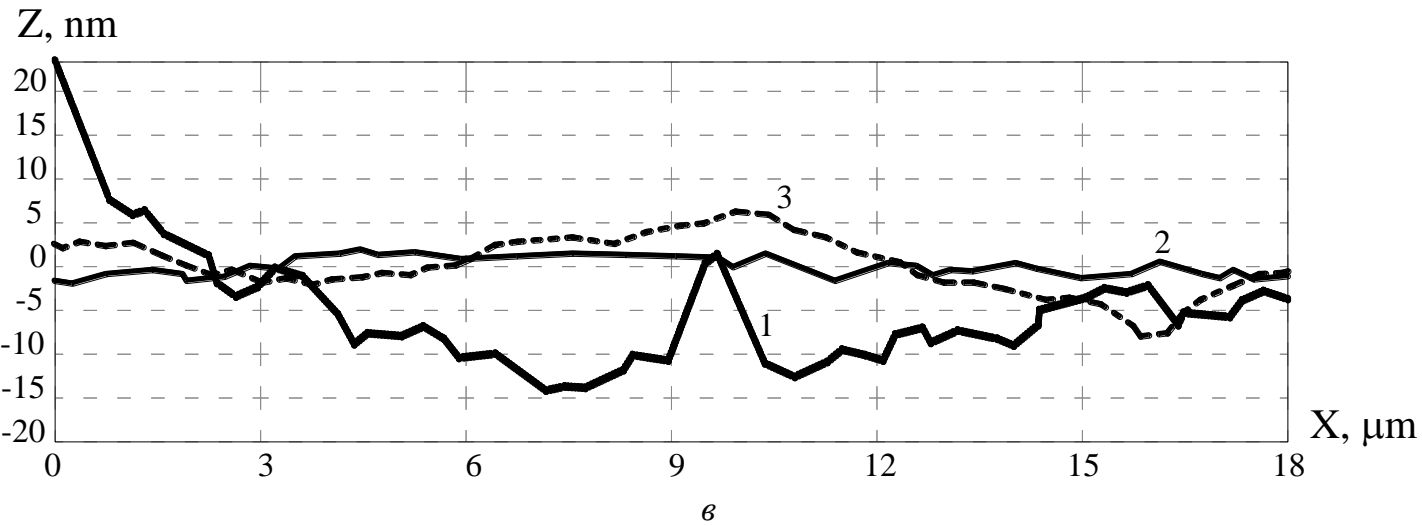

Рис. 5. Мікрогеометрія (а, б) та профіль вздовж лінї $A-B$ (в) ділянки поверхні (10х10 мкм) пластини зі скла К8, яку було оброблено електронним потоком (а) та скануючим лазерним променем (б):

1 - профіль вихідної поверхні; 2 - профіль поверхні, обробленої електронним потоком; 3 - профіль поверхні, обробленої скануючим лазерним променем

При цьому, як можна побачити на рисунку 5, на поверхнях пластин, які були оброблені скануючим лазерним променем, спостерігалася хвилястість. Збільшення потужності лазерного випромінювання 3 одночасним збільшенням фокусної відстані збільшує хвилястість, що вірогідно пов'язано зі збільшенням в'язкості діелектричного аморфного матеріалу на повітрі. Подальше ж збільшення потужності лазерного випромінювання 315 до 25 Вт призводить до утворення на оптичних поверхнях мікротріщин 3 подальшою руйнацією поверхні.

\section{Висновки:}

1. Досліджено режими роботи ЕПГ Пірса залежно від її енергетичних характеристик. Показано, що при ширині анодної щілини $b_{a}=2,0$ мм можна реалізувати основні технологічні режими низькоенергетичної ЕПМО діелектриків (у тому числі оптичного скла), що відповідають II CTВ, тоді як зменшення та збільшення значення $b_{a}$ обмежує діапазон технологічних режимів для I СТВ та для III СТВ відповідно; 
2. Проведено порівняння результатів електронно-променевої мікрообробки діелектриків за оптимальних режимів з результатами їх лазерної поверхневої обробки, що дозволило встановити зменшення залишкових мікронерівностей поверхні для оптичного скла К8 з 40...110 нм до 1,5...6,5 нм за ЕПМО та до 3,3...7,8 нм за ПЛО. При цьому поверхнева лазерна обробка не дозволяє усунути хвилястість поверхні, що пов'язана зі специфікою взаємодії лазерного променя з поверхнею оптичного матеріалу, тоді як під час обробки електронним потоком стрічкової форми виникнення такої хвилястості не спостерігається.

3. Показано, що електронно-променева мікрообробка поверхонь діелектричних матеріалів на прикладі пластин 3 оптичного скла К8 дозволяє підвищити відтворюваність результатів такої мікрообробки за чистотою та залишковим нанорельєфом на 18...25 \%.

\section{Список використаної літератури:}

1. Оптоелектроніка і мікрооптика - перспективні галузі науки і техніки / Г.В. Канашевич, В.А. Ващенко, В.М. Лукашенко та ін. // Вісник ЧДТУ. - 2002. - № 2. - С. 52-62.

2. Kanashevich G.V. Micro-treatment of surfaces of plates made of optical glass with a low-power electronic stream of a band form / G.V. Kanashevich // The 7th World Congress on Recovery, Recycling and Reintegration \& China International 3R Exhibition, Beijing, China, Sept. 25-29, 2005. - $7 \mathrm{p}$

3. Підвищення мікротвердості та зносостійкості поверхонь елементів виробів 3 оптичного скла мікрообробкою електронним потоком у вакуумі / В.С. Антонюк, Ю.І. Коваленко, Ю.Ю. Бондаренко, М.О. Бондаренко // Вісник Житомирського державного технологічного університету. Серія : Технічні науки. - Житомир : ЖДТУ, 2015. - № 1 (72). - С. 3-8.

4. Control of spatial characteristics of the ribbon-shaped electron stream in the process of processing optical coverings of optoelectronics products / R.Gaidash, S.Ralchenko, V.Medyanyk, M.Bondarenko // Machines. Technologies. Materials. - 2018. - Vol. 12, Issue 10. - P. 398-401.

5. Research of Volt-Ampere Characteristics of the Wire Pierce Electron Gun at Electron-Beam Microprocessing of Dielectrics / M.Bondarenko, V.Antonyuk, Yu.Kovalenko and other // Ukrainian Journal of Mechanical Engineering and Materials Science. - 2018. - Vol. 4, № 1. - P. 58-64.

6. Дослідження та формування стрічкового електронного потоку для мікрообробки поверхонь матеріалів / М.П. Рудь, М.О. Бондаренко, Ю.І. Коваленко та ін. // Нові матеріали і технології в металургії та машинобудуванні. - Запоріжжя : ЗНТУ, 2012. - № 2. - С. 58-63.

7. Kanashevich G.V. Superficial micro- and nanostructures in optical glass, which were formed by band electronic stream / G.V. Kanashevich, L.I. Konopalceva // Clusters and Nanostructured materials (CNM'2006) : materials of International meeting, Uzhgorod, «Karpaty», Ukraine, October 9-12, 2006. - P. 2-8.

8. Коваленко Ю.І. Исследование распределения энергии в зоне действия денточного электронного потока / Ю.І. Коваленко, В.С. Антонюк, Л.Г. Полонский // Перспективи розвитку машинобудування та транспорту 2019 : зб. тез доповідей I Міжнародної науково-технічної конференції, 13-15 травня 2019 р. - Вінниця : ПП «ТД «Едельвейс і К», 2019. - С. 295-296.

\section{References:}

1. Kanashevich, G.V., Vaschenko, V.A., Lukashenko, V.M. and other (2002), «Optoelektronika i mikrooptyka perspektyvni haluzi nauky i tekhniky», Visnyk Cherkas'kogo derzhavnogo tehnologichnogo universytetu, No. 2, pp. 52-62.

2. Kanashevich, G.V. (2005), «Micro-treatment of surfaces of plates made of optical glass with a low-power electronic stream of a band form», The 7th World Congress on Recovery, Recycling and Reintegration \& China International 3R Exhibition, Beijing, China, Sept. 25-29, 7 p.

3. Antonyuk, V.S., Kovalenko, Yu.I., Bondarenko, Yu.Yu. and Bondarenko, M.O. (2015), «Pidvyshchennia mikrotverdosti ta znosostiikosti poverkhon elementiv vyrobiv z optychnoho skla mikroobrobkoiu elektronnym potokom u vakuumi», Visnyk Zhytomyrskoho derzhavnoho tekhnolohichnoho universytetu, Seriia Tekhnichni nauky, ZhDTU, Zhytomyr, No. 1 (72), pp. 3-8.

4. Gaidash, R., Ralchenko, S., Medyanyk, V. and Bondarenko, M. (2018), «Control of spatial characteristics of the ribbon-shaped electron stream in the process of processing optical coverings of optoelectronics products», Machines. Technologies. Materials, Vol. 12, Issue 10, pp. 398-401.

5. Bondarenko, M., Antonyuk, V., Kovalenko, Yu. and other (2018), «Research of Volt-Ampere Characteristics of the Wire Pierce Electron Gun at Electron-Beam Microprocessing of Dielectrics», Ukrainian Journal of Mechanical Engineering and Materials Science, Vol. 4, No. 1, pp. 58-64.

6. Kovalenko, Yu.I., Rud, M.P., Bondarenko and other (2012), «Doslidzhennia ta formuvannia strichkovoho elektronnoho potoku dlia mikroobrobky poverkhon materialiv», Novi materialy $i$ tekhnolohii $v$ metalurhii ta mashynobuduvanni, ZNTU, Zaporizhzhia, No. 2, pp. 58-63.

7. Kanashevich, G.V. and Konopalceva, L.I. (2006), «Superficial micro- and nanostructures in optical glass, which were formed by band electronic stream», Clusters and Nanostructured materials (CNM'2006), materials of International meeting, «Karpaty», Uzhgorod, Ukraine, October 9-12, 2006, pp. 2-8.

8. Kovalenko, Yu.I., Antonyuk, V.S. and Polonskiy, L.G. (2019), «Issledovanie raspredelenija enerhii v zone dejstvija lentochnoho elektronnoho potoka», Perspektyvy rozvytku mashynobuduvannia ta transportu - 2019, zb. tez dopovidei I Mizhnarodnoi naukovo-tekhnichnoi konferentsii, 13-15 travnia 2019 r., PP «TD «Edelveis i K», Vinnytsia, pp. 295-296. 
Коваленко Юрій Іванович - старший викладач кафедри фундаментальних дисциплін та прикладного матеріалознавства Черкаського державного технологічного університету.

Наукові інтереси:

- обробка діелектричних матеріалів у вакуумі;

- електронно-променева обробка матеріалів.

E-mail: kovalenkoyi@ukr.net.

Бондаренко Максим Олексійович - доктор технічних наук, доцент, доцент кафедри приладобудування, мехатроніки та комп'ютеризованих технологій Черкаського державного технологічного університету.

Наукові інтереси:

- атомно-силова мікроскопія;

- наноінженерія поверхонь діелектриків.

E-mail: maxxium23@gmail.com.

Антонюк Віктор Степанович - доктор технічних наук, професор, завідувач кафедри виробництва приладів Національного технічного університету України «Київський політехнічний інститут імені Ігоря Сікорського».

Наукові інтереси:

- обробка матеріалів;

- нанометричні дослідження поверхонь діелектриків.

E-mail: victor.antoniuk@gmail.com.

Стаття надійшла до редакції 20.02.2020. 